\title{
What do State Institutions Say? Twitter as a Public Communication Tool During the Impeachment of Dilma Rousseff*
}

\author{
Francisco Paulo Jamil Marques \\ https://orcid.org/0000-0002-5256-1964 \\ Universidade Federal do Paraná, Curitiba, Paraná, Brazil \\ Fellipe Herman \\ https://orcid.org/0000-0002-1249-9051 \\ Universidade Federal do Paraná, Curitiba, Paraná, Brazil \\ Andressa Butture Kniess \\ https://orcid.org/0000-0002-1337-5376 \\ Universidade Federal do Paraná, Curitiba, Paraná, Brazil \\ Jackeline Saori Teixeira \\ https://orcid.org/0000-0002-8828-2158 \\ Universidade Federal do Paraná, Curitiba, Paraná, Brazil
}

The objective of this article is to analyze the content of public communications in situations of political crisis. We aim to establish whether and to what extent there was partisan instrumentalization of the digital social media channels administered by State institutions during the impeachment of Dilma Rousseff. We analyzed all posts published between 2015 and 2016 on the official Twitter profiles of Brazil's Chamber of Deputies, Federal Senate, Presidential Palace and Federal Supreme Court. We considered all posts with the words 'impeachment', 'impedimento', ('impeachment') 'afastamento', ('impeachment') and 'golpe' ('coup') ( $\mathrm{n}=795)$. Our methodology comprised a combination of quantitative (descriptive statistics) and qualitative (content analysis) strategies. We found that the Federal Senate's twitter profile most frequently posted the word 'impeachment', while the term 'golpe' was most frequently posted by the Presidential Palace profile. Over half of the publications fit into the category of 'dissemination of news'. The Presidential Palace's Twitter profile exhibited a distinct pattern of behavior, predominantly posting tweets associated with the 'promotion of ideas and expression of positions'. Therefore, the Presidential Palace favored a communications strategy with a partisan bias. This research is relevant as it uses empirical data to discuss phenomena tied to studies on public and political communication.

Keywords: Political communication; public communication; social media; Twitter; impeachment.

http://dx.doi.org/10.1590/1981-3821201900030005

For data replication, see: https://doi.org/10.7910/DVN/ZRXEL9

This publication is registered under a CC-BY Licence.

*This work was supported by the Brazilian National Council for Scientific and Technological Development (Process n. 309967/2017-1) and the Coordination for the Improvement of Higher Education Personnel (001). 
The use of digital communication is becoming increasingly common in

Brazil (BRAZIL, 2015). It is therefore pertinent to discuss the political use of social networking sites, as they offer political actors the opportunity to publish content directly and to assess the responses of their interlocutors (RUEDIGER, 2017).

A significant amount of research has already been dedicated to examining such elements as the character of posts published on certain profiles. Such diagnoses are almost always accompanied by measurements of total numbers of followers, numbers of users followed, or numbers of posts liked (NIELSEN and VACCARI, 2013). Such studies tend to describe the dynamics of political actors' individual use of communication tools and to search for patterns according to party affiliation, age, gender and so on (EVANS, CORDOVA and SIPOLE, 2014; MARQUES, AQUINO and MIOLA, 2014).

This article differs from the lion's share of the research mentioned above for two reasons. First, the emphasis here is not on how particular leaders use social networking sites personally, but on how State institutions use them. Second, this article proposes investigating how these institutions employ digital communication in times of political crisis. This approach demands a qualitative methodological strategy distinct from those used so far in other publications in this field (AGGIO, 2016; CASERO-RIPOLLÉS, SINTES-OLIVELLA and FRANCH, 2017; LASSEN and BROWN, 2011; MARQUES and MONT'ALVERNE, 2016; RAMOS-SERRANO, GÓMEZ and PINEDA, 2016).

During the early years of digital communication networks, scholars argued that most State bodies favored what used to be known as 'institutional presence' - that is, an emphasis on providing primary information, such as addresses, contact telephone numbers, or the biographical details of important personnel (GOMES, 2005; LEE and VANDYKE, 2015). The combination of increased access to digital communication resources in recent years and increased sophistication in public service provision raises another question: to what degree does public-facing communication on the part of State entities differ from communication used to address political and party interests? In other words, do public institutions use social media to increase transparency, participation and debate (MIOLA and 
MARQUES, 2017; ZÉMOR, 2012), or do they seek to fulfill an instrumental role by aiming to favor the perspectives of leaders, governments and parties (BARROS and MIOLA, 2015; BUCCI, 2015; WEBER, 2007)? In order to investigate whether and to what extent State public communications are instrumentalized in this way, we proposed a study of posts on the official Twitter profiles of four Brazilian State institutions: the Chamber of Deputies, the Federal Senate, the Presidential Palace and the Federal Supreme Court (STF).

Twitter was chosen in view of the fact that official documents, such as the 'Guidelines on Social Media Use' (BRAZIL, 2014) prepared by the Office of the Secretary of Communication of the Office of the President, suggest that Twitter should be given precedence over other forms of social media as it is, in the opinion of the Office of the Secretary, a "popular [tool] among political elites and opinion-makers" (BRAZIL, 2015, p. 50).

This article considers only posts addressing the impeachment process that ultimately ousted former Workers' Party (PT) president Dilma Rousseff, accused of having committed a 'crime of responsibility'. The period we looked at ran from January 2015 to December 2016. This time frame was chosen due to its political importance. Key political events included: pro- and anti-impeachment street demonstrations (March, April, August and December 2015); the formal impeachment process, which started with the acceptance of the complaint by the Chamber of Deputies in December 2015; the opening of the Senate inquiry in May 2016; and the final hearing, held between August 26 and 31, 2016.

The four Twitter profiles that we chose were selected because of the central importance of the four entities throughout the impeachment process: the Presidential Palace houses the leadership of the Federal Executive Branch; the Chamber of Deputies and the Federal Senate decide on whether an impeachment trial can be opened and carried forward; and the Federal Supreme Court rules on the constitutionality of the proceedings. An understanding of how each entity used Twitter during this politically epochal period is therefore of fundamental importance. The questions that guided our research were: how did these Twitter profiles behave during this moment of political crisis? To what extent is it possible 
to say that these Twitter profiles were instrumentalized in a partisan fashion during the impeachment process?

Based on the literature review - presented in the theoretical discussion our working hypothesis is: 'The official Twitter profiles managed by State institutions favor the publication of posts promoting political position-taking. This indicates instrumentalization of the available communication tools'.

We took a quantitative approach to measuring the frequency of the terms 'impeachment', 'impedimento' (impeachment), 'afastamento' (impeachment) and 'golpe' (coup) in posts on the profiles we examined. A quantitative stratagem of this type allows for a qualitative approach - made possible through Content Analysis. Examining content allows us to diagnose the ways in which these entities handled the impeachment process in greater detail.

The article is divided into four sections. In the first one, we discuss the concept of State entities using social networking sites for public communication purposes. In the second, we detail the methodological strategies we used for this article. In the third section, we present our quantitative and qualitative data. In the conclusion, we discuss our findings and compare them with the relevant literature.

\section{The use of digital social media by State entities for public communication}

Public communication involves at least two dimensions: firstly, there is the normative dimension, according to which the primary purpose of State communication is to encourage civic participation and thereby improve service provision and social control through transparency mechanisms; the second dimension privileges strategic communication that seeks to construct public images with the goal of conquering or maintaining power niches (BUCCI, 2015; MIOLA and MARQUES, 2017). Canel and Sanders (2016) recognize this last facet in their treatment of examples where government communications (using tools derived from the public relations industry) seeks to influence decision-makers in order to gain support for particular policies.

Thus, on the one hand, government entities emphasize the potential of social media to aid the public in making decisions by providing them with relevant information; on the other, scholars working in this area are clearly worried about public communications being manipulated to serve partisan interests. This 
article understands the instrumentalization of communication as the use of media to direct messages with the object of fulfilling particular interests (EBERWEIN et al., 2015). A body of work has dedicated itself to examining the extent to which political groups in government positions seek to influence public communication to serve their own interests (BUCCI, 2015; MIOLA, 2009).

The literature illustrates several cases of instrumentalization of public communication. In Brazil, political interference in public communications has been shown to go back as far as the Vargas era (JAMBEIRO, 2002). The rise of democratic governments in recent decades has not been free of criticism of how State entities communicate: “Brazil's so-called 'public communication' has almost nothing 'public' about it. It is simply indoctrination. [...] Can an ideological propaganda factory be called 'public'?" (BUCCI, 2015, p. 16).

Lashley (1992), writing about the United States of America - specifically the communication strategies of the Johnson, Nixon, Carter and Reagan administrations - finds that governments "imposed policy preferences that not only determined the appropriation outcomes but also defined the organizational structure, decisionmaking processes and programming content of public television" (LASHLEY, 1992, p. 772). Graber (2002) points out that all types of political communication - even public State communication - contemplate certain corporate interests. She identifies contests between the 'technical' and 'political' objectives of communication by public agencies.

It should be noted, however, that not every strategic communication approach implies political instrumentalization. Graber (2002), for example, regards attempts by public entities to convince and persuade as an inherent component of democratic government. In other words, communication can be regularly used to create positive institutional images and reputations - and these images legitimize the actions of public bodies (CONRAD and TERRY, 2015). In the case of digital social media, the literature highlights the need for public institutions to establish strategies for using these platforms, by taking into account their goals as well as their technical and human resources (CAMPILLO-ALHAMA and MARTÍNEZSALA, 2017; TANDAZO, GALARZA and BENAVIDES, 2016). 
It is clear, then, that communicating with citizens to create and maintain an institutional image is not the same as using public communication to favor political parties or actors. The institutions analyzed here use their communication channels to convince citizens that their actions are beneficial. In the light of the foregoing, this paper considers that instrumentalization of State communication has taken place when favoritism is shown towards certain political parties or actors. In other words, instrumentalization goes against the normative assumptions underpinning State public communication (MIOLA and MARQUES, 2017).

With this in mind, it is essential to verify the extent to which instrumentalization manifests itself in social networking sites - especially in times of political crisis. It should also be emphasized that part of the literature characterizes Twitter as a 'chaotic' environment, given both the amount of posts published and the speed with which messages are updated (HONEYCUTT and HERRING, 2009).

A number of studies in the area highlight the growing adoption of Twitter by key political leaders - if not to facilitate citizen interaction, at least to announce decisions or political positions (ENLI, 2017; GOLBECK, GRIMES and ROGERS, 2010; MARQUES, AQUINO and MIOLA, 2014; OTT, 2017; PARMELEE and BICHARD, 2011; ROSSINI and LEAL, 2012). Twitter has thus become an essential environment for announcing government decisions and, of course, for promoting public images (ENLI and SKOGERBØ, 2013; JACKSON and LILLEKER, 2011).

A considerable part of the studies examining Twitter as a political tool focus on the electoral communication strategies employed by candidates (GOMES et al., 2009; VERGEER, HERMANS and SAMS, 2013; WILLIAMS and GULATI, 2013). The possibility of establishing a channel of communication unfiltered by journalists - the adoption of which does not necessarily imply greater willingness to interact with voters (HEMSLEY et al., 2018) - has been a key focus of research (AHARONY, 2012; ENLI and SKOGERB Ø, 2013; JACKSON and LILLEKER, 2011; JUNGHERR, 2016; LARSSON and KALSNES, 2014). There have been many research articles published that attempt to define the discursive differences characteristic of each communication strategy (BOR, 2013; LASSEN and BROWN, 2011; UTZ, 2009). 
Although a significant portion of articles on political communication via Twitter focus on election periods, it is well known that Twitter is also regularly used by State bodies. They use digital communication platforms to provide information and services and to promote participation and social control of public administration (BARROS and MIOLA, 2015; KHAN, YOON and PARK, 2014).

According to Mergel (2013), official communication strategies usually employ three approaches: push, pull and networking. The push strategy involves simply sending information to the public through digital social media; in the pull strategy, users are redirected to websites, which opens a space for networking, and this provides opportunities for greater engagement. It is possible that individual institutions may choose to emphasize a particular approach (dissemination of information or interaction with citizens).

This paper proposes to investigate not only the regular use of social networks by official bodies, but also to examine how specific scenarios, such as political crises, can affect the characteristics of online public communications.

It is important to clarify that the 'crisis' here refers to the process, beginning in December 2015, of removing Dilma Rousseff from the office of president of the Republic. It was in that month that then president of the Chamber of Deputies, Eduardo Cunha (Brazilian Democratic Movement (MDB)), accepted the complaint submitted by the lawyers Hélio Bicudo, Janaína Paschoal and Miguel Reale Junior. The allegation of 'crime of responsibility' was contested by various sectors of society: legal experts, politicians and national and international entities described the impeachment as a 'coup' motivated, among other reasons, by a desire for personal revenge on the part of Cunha (who had not received the help that he had sought from Rousseff's Workers' Party (PT) to bar the investigation of complaints laid against him in Congress) ${ }^{1}$.

Importantly, this was not the first time that a president elected by popular vote had faced removal from office: Fernando Collor was impeached in 1992 (SALLUM JR. and CASARÃO, 2011). Part of the literature devoted to studying the different processes for removing elected officials in Latin America (PÉREZ-LIÑÁN,

\footnotetext{
${ }^{1}$ See: <https://www.nytimes.com/2016/04/20/world/americas/dilma-rousseff-impeachment-
} brazil.html>. Accessed on August, 22, 2018. 
2007) highlights the relevance of at least three agents in such crises: masscommunication institutions, often accused of working against the democratic order (ALBUQUERQUE, 2017); the Legislative Branch, riven with internal conflicts; and popular discontent, especially widespread rejection of politicians by the public who voted them into office (ALONSO, 2017).

Before moving on to the next point, it is essential to point out that the literature on the interface between communication and crisis management deals with situations from both the corporate and political worlds. The existence of a dispute concerning the way events are framed and interpreted by public opinion is a frequent finding in the area of organizational and administrative communication (BOIN, HART and McCONNELL, 2009; STURGES, 1994). Many studies noted the strategic adoption of dramatic gestures, the creation of pseudo-events and the promotion of labels aimed at raising awareness in an audience (in the case of the hashtags (\#NãoVaiTerGolpe [ThereWillBeNoCoup] and \#StopCoupInBrazil) during the impeachment of Rousseff and in similar crises. The purpose of communication at such times is to set out courses of action that can counter interpretations of the world contrary to the interests of those disseminating the messages (HART, 1993). Empirical research into the extent to which such crises affect the public communication standards adopted by State institutions offers new insights into the discussion of the ways in which digital communication is used.

\section{Methodological strategies}

In order to answer the research questions presented in the introduction, a quantitative and qualitative study was proposed with the aim of verifying: 01 . the frequency of posts dealing with one of the following keywords: 'impeachment', 'impedimento', 'afastamento' and 'golpe'; and 02. the content linked to these tweets. Our hypothesis, derived from the literature, is that: 'The official Twitter profiles managed by State institutions favor the publication of posts promoting political position-taking. This indicates instrumentalization of the available communication tools'.

We started out by creating a general overview of each profile that considered its creation date and number of followers. We then manually collected posts from 2015 and 2016 that contained the words 'impeachment', 'impedimento', 
'afastamento' and 'golpe'. This took place between 08 and 13 June 2017; we used Twitter's own search tool for maximum accuracy. Our search yielded 860 tweets containing at least one of the keywords mentioned above. After undertaking a double-checking process, however, we noted that 65 posts were unrelated to the impeachment of President Rousseff (in cases where the terms 'impedimento' and 'afastamento' related to other matters) and this reduced our corpus of eligible tweets to 795 .

Our next step was to create Content Analysis categories. In doing so, we referred to both our corpus (BARDIN, 1977) and previous tweet categorization studies (AGGIO, 2016; BAXTER, MARCELLA and O'SHEA, 2016; CASERORIPOLLÉS, SINTES-OLIVELLA and FRANCH, 2017). We then drew up a codebook specific to this study.

Analysis of the posts was based on two variables: 01 . the first was the form of the tweet (was there direct interaction with other users? Understanding this helps verify to what extent any instrumentalization is related to mentions of the political actors); 02. the second variable related to content (subdivided into seven mutually exclusive categories). Our codebook is detailed below.

\section{Tweet form (direct interaction with users via re-tweet, response, or direct mention of “@” by users)}

Dummy variable that identifies if a tweet interacts directly with other accounts. These interactions are recorded when an institution uses the '@’ symbol to refer to other users or when it re-tweets or replies to a post. This variable relates to a specific characteristic of Twitter, i.e., the possibility of using interaction as a communication strategy. This includes using interaction with other users as part of measures aimed at segmenting the target audience or valorizing the views of supporters (HEMSLEY et al., 2018).

\section{Example}

\#GovInforma o desespero da @Veja, @RevistaISTOE e @RevistaEpoca que 'denunciam' compra de votos contra impeachment. (\#GovInforms of @Veja, 
@RevistaISTOE and @RevistaEpoca's frustration, who 'denounced' payments for votes against impeachment) ${ }^{2}$.

\section{Tweet content}

Variable divided into seven categories based on the main subject in each tweet. The categories set out below are mutually exclusive; we have included example posts for each category.

Framework 01. Categories for analysis of post content

\begin{tabular}{|c|c|c|}
\hline Category & Description & Example \\
\hline $\begin{array}{l}\text { 01. Steps in the } \\
\text { impeachment } \\
\text { process }\end{array}$ & $\begin{array}{l}\text { Tweets that merely report on the general steps } \\
\text { of the impeachment process, such as dates } \\
\text { when certain formal steps in the process will } \\
\text { occur. }\end{array}$ & $\begin{array}{l}\text { \#impeachment - De } 07 \text { a } 12 \text { de } \\
\text { julho - alegações finais da } \\
\text { acusação. [\#impeachment - July } \\
07-12 \text { - prosecution's closing } \\
\text { arguments.] (Senate - 06/23/16: } \\
\text { https://goo.gl/sZ1LgD). }\end{array}$ \\
\hline $\begin{array}{l}\text { 02. Media } \\
\text { agenda }\end{array}$ & $\begin{array}{l}\text { Invitation to follow radio broadcasts } \\
\text { (statements, interviews) or to consult } \\
\text { materials related to the impeachment trial } \\
\text { sessions; announcements of when institutional } \\
\text { representatives will give interviews or make } \\
\text { statements. }\end{array}$ & $\begin{array}{l}\text { Acompanhe ao vivo a sessão para } \\
\text { discussão do pedido de } \\
\text { impeachment de Dilma pelo } \\
\text { YouTube. [Watch the } \\
\text { Congressional hearing on the } \\
\text { request to impeach Dilma live on } \\
\text { YouTube.] https://goo.gl/71znIa } \\
\text { (Chamber of Deputies - } \\
\text { 04/15/16: } \\
\text { https://goo.gl/LNZmdv). }\end{array}$ \\
\hline $\begin{array}{l}03 . \\
\text { Dissemination } \\
\text { of news }\end{array}$ & $\begin{array}{l}\text { Indication of factual or news publications } \\
\text { divulged by the institution (content with no } \\
\text { apparent political position); tweets that utilize } \\
\text { any partisan ideological terms do not fall into } \\
\text { this category. }\end{array}$ & $\begin{array}{l}\text { Negada liminar em que ex- } \\
\text { presidente Dilma buscava } \\
\text { suspender impeachment: [The } \\
\text { injunction that ex-President } \\
\text { Dilma had hoped would suspend } \\
\text { her impeachment has been } \\
\text { denied:] https://goo.gl/1W1XKB } \\
\text { (STF - 10/20/2016: } \\
\text { https://goo.gl/mLXQQI). }\end{array}$ \\
\hline $\begin{array}{l}04 \text {. Reporting } \\
\text { on political } \\
\text { achievements }\end{array}$ & $\begin{array}{l}\text { Direct mention of previous political plans or } \\
\text { programs, as well as ongoing initiatives or } \\
\text { promised future ones. }\end{array}$ & $\begin{array}{l}\text { @AgoraNoPanalto: Dilma lança } \\
\text { navio e reafirma R\$ 3,5 bi para } \\
\text { @DefesaGovBr ao som de 'não vai } \\
\text { ter golpe' [Dilma launches ship, } \\
\text { reaffirming R\$ } 3.5 \text { billion to } \\
\text { @DefesaGovBr to the sound of } \\
\text { 'there will be no coup'] - } \\
\text { http://bit.ly/1UWfeVi. } \\
\text { (Presidential Palace - } \\
\text { 04/06/2016: } \\
\text { https://goo.gl/tZB75e). }\end{array}$ \\
\hline
\end{tabular}

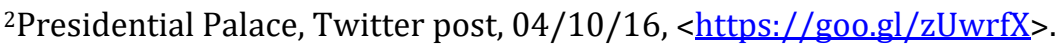


05. Criticism and negative campaigning
Tweets with content that directly attacks other institutions or policymakers.

\author{
Dilma diz a @randolfeap que \\ impeachment começou com \\ chantagem de Cunha [Dilma tells \\ @randolfeap that impeachment \\ began with blackmail by Cunha] \\ http://bit.ly/2c0YU3E (Federal \\ Senate - 08/29/2016: \\ https://goo.gl/Ic3PWw). \\ 'Combate à corrupção se faz
dentro dos marcos legais, o resto
é golpe!', Camila Gomes
\#EmDefesaDaDemocracia
['Fighting corruption must be
done within the law, everything
else is a coup!', Camila Gomes
\#InDefenseOfDemocracy]
(Presidential Palace -
03/22/2016:
https://goo.gl/5PpHRD).
'Todo mundo de olho no Senado
durante o julgamento de
impeachment'. ['All eyes on the
Senate during the impeachment
trial'.] (Federal Senate -
08/27/2016:
https://goo.gl/Tm3Z4b).
}

06. Promotion of ideas and expression of positions

07. Others
Publications that exalt political ideologies or express political opinions and/or positions.
Tweets that do not fit into any of the categories outlined above.

Source: Elaborated by the authors.

As is apparent, the categories related to the 'tweet content' variable were structured to identify whether the institutions were examined favored normative public communication (categories 01,02 , or 03) or instrumentalized Twitter for partisan communication (categories 04,05 , or 06 ).

With our categories at the ready, we started exploring the material. At this stage, three coders were trained to classify the contents of the tweets. After the exploratory stage, we undertook a reliability test with 84 tweets (slightly more than $10 \%$ of the corpus) posted by the four profiles (the number of posts used in the test was proportional to the presence of each institution in the corpus). We opted for the Krippendorff's alpha test because of its higher statistical power and the fact that it meets all the criteria for a good measure of reliability (HAYES and KRIPPENDORFF, 2007). In addition, Krippendorff's alpha stands out as one of the most frequently used tests in political communications research (MAIA, BOTELHO and MUNDIM, 2011; RAMOS-SERRANO, GÓMEZ and PINEDA, 2016). These results allowed us to adjust the methods that the three coders used to classify tweets. At the end of the 
process, we achieved a Krippendorff alpha score of 0.795 - considered reliable by literature in the area (KRIPPENDORFF, 2004). It is important to point out that we only took into consideration the text published in each tweet, i.e., we did not consider any images or the content of any links.

In order to provide answers to our initial questions, the following topic includes, in addition to the descriptive frequencies, the chi-squared and Cramér's V statistical tests. The chi-squared test verifies if there is a statistically significant association between categorical variables; the Cramér's V test indicates the degree of this association. We also present the standardized residuals of the contents of the posts (allowing for the identification of differences between observed and expected values in a given distribution). Finally, we present the correspondence analysis - an exploratory data technique that allows for graphic visualization of categorical variables (HAIR JR. et al., 2009).

\section{Presentation of data}

Table 01 presents information on the profiles studied in this project. As can be seen, the profile of the Federal Supreme Court has the most followers at the time of data collection. The Twitter accounts analyzed in this project were created between May and August of 2009.

Table 01. Data from the Twitter profiles that we analyzed

\begin{tabular}{llll}
\hline Account name & Profile & Created & Followers \\
\hline Chamber of Deputies & @CamaraDeputados & $07 / 31 / 2009$ & 625,335 \\
Federal Senate & @SenadoFederal & $05 / 14 / 2009$ & 565,173 \\
Presidential Palace & @AgoraNoPlanalto & $06 / 01 / 2009$ & 716,783 \\
Federal Supreme Court & @STF_oficial & $08 / 24 / 2009$ & $1,496,840$ \\
\hline
\end{tabular}

Source: Elaborated by the authors, with data from Twitter. Data collection carried out on June, 08, 2017.

Table 02 shows the distribution of the 795 tweets from the four institutional profiles making up the research corpus. The Federal Senate, with 477 tweets, was the profile with the highest number of posts, representing almost $60 \%$ of all publications during the period. Next was the Chamber of Deputies, with 132 posts, the Presidential Palace with 101 and the Federal Supreme Court with 85. 
Table 02. Quantity of tweets between 2015 and 2016 with the keywords

\begin{tabular}{|c|c|c|c|c|c|c|c|c|c|}
\hline \multirow[b]{3}{*}{ Total tweets } & \multicolumn{2}{|c|}{$\begin{array}{l}\text { Presidential } \\
\text { Palace }\end{array}$} & \multicolumn{2}{|c|}{$\begin{array}{c}\text { Chamber of } \\
\text { Deputies }\end{array}$} & \multicolumn{2}{|c|}{$\begin{array}{l}\text { Federal } \\
\text { Senate }\end{array}$} & \multicolumn{2}{|c|}{$\begin{array}{c}\text { Federal Supreme } \\
\text { Court }\end{array}$} & \multirow{2}{*}{$\begin{array}{c}\text { Total } \\
\mathrm{N}\end{array}$} \\
\hline & $\mathrm{N}$ & (\%) & $\mathrm{N}$ & (\%) & $\mathrm{N}$ & (\%) & $\mathrm{N}$ & (\%) & \\
\hline & 101 & $13 \%$ & 132 & $17 \%$ & 477 & $60 \%$ & 85 & $11 \%$ & 795 \\
\hline
\end{tabular}

Source: Elaborated by the authors, with data from Twitter.

Although our corpus consists of the 795 tweets presented above, it should be noted that the four keywords highlighted in this investigation ('impeachment', 'impedimento', 'afastamento' and 'golpe') were used 821 times within them due to repetition or use of more than one term per tweet.

For instance, the Presidential Palace profile published a total of 101 tweets containing at least one of the keywords during the period in question. However, there were occasions when 'impeachment' and 'golpe' were cited simultaneously used in the same tweet. This can be seen in the following post: “@Dilmabr: 'Constituição prevê 'impeachment', mas não a invenção de motivos, e é isso que chamo de 'golpe' [The Constitution provides for 'impeachment', but not for making up motives and this is what I call a 'coup']"3.

Table 03 shows the frequency with which the profiles used the terms. Note that the Presidential Palace was the institution that most mentioned the word 'golpe', followed by the Federal Senate. The Chamber of Deputies used this term only once. The Federal Supreme Court did not use this term during the period.

Table 03. Frequency of keywords between 2015 and 2016

\begin{tabular}{|c|c|c|c|c|c|c|c|c|c|}
\hline & \multicolumn{2}{|c|}{ Impeachment } & \multicolumn{2}{|c|}{$\begin{array}{l}\text { Impedimento } \\
\text { [impeachment] }\end{array}$} & \multicolumn{2}{|c|}{$\begin{array}{c}\text { Afastamento } \\
\text { [impeachment] }\end{array}$} & \multicolumn{2}{|c|}{ Golpe [coup] } & \multirow{2}{*}{$\begin{array}{c}\text { Total } \\
\mathrm{N}\end{array}$} \\
\hline & $\mathrm{N}$ & $(\%)$ & $\mathrm{N}$ & $(\%)$ & $\mathrm{N}$ & $(\%)$ & $\mathrm{N}$ & $(\%)$ & \\
\hline $\begin{array}{l}\text { Chamber of } \\
\text { Deputies }\end{array}$ & 129 & $96 \%$ & 01 & $1 \%$ & 03 & $2 \%$ & 01 & $1 \%$ & 134 \\
\hline Federal Senate & 449 & $92 \%$ & 07 & $1 \%$ & 14 & $3 \%$ & 18 & $4 \%$ & 488 \\
\hline Presidential Palace & 68 & $60 \%$ & 0 & $0 \%$ & 02 & $2 \%$ & 43 & $38 \%$ & 113 \\
\hline $\begin{array}{l}\text { Federal Supreme } \\
\text { Court }\end{array}$ & 79 & $92 \%$ & 03 & $3 \%$ & 04 & $5 \%$ & 0 & $0 \%$ & 86 \\
\hline Total & 725 & & 11 & & 23 & & 62 & & 821 \\
\hline
\end{tabular}

Source: Elaborated by the authors, with data from Twitter.

${ }^{3}$ Presidential Palace, Twitter Post, 12/16/2015, <https://goo.gl/8nRNLW>. 
Graph 01 shows the evolution over time of the 795 posts between January 2015 and December 2016. The first to publish a post with the word 'impeachment' was the Federal Senate, on February 10, 2015.

Graph 01. Monthly distribution of the tweets by profile

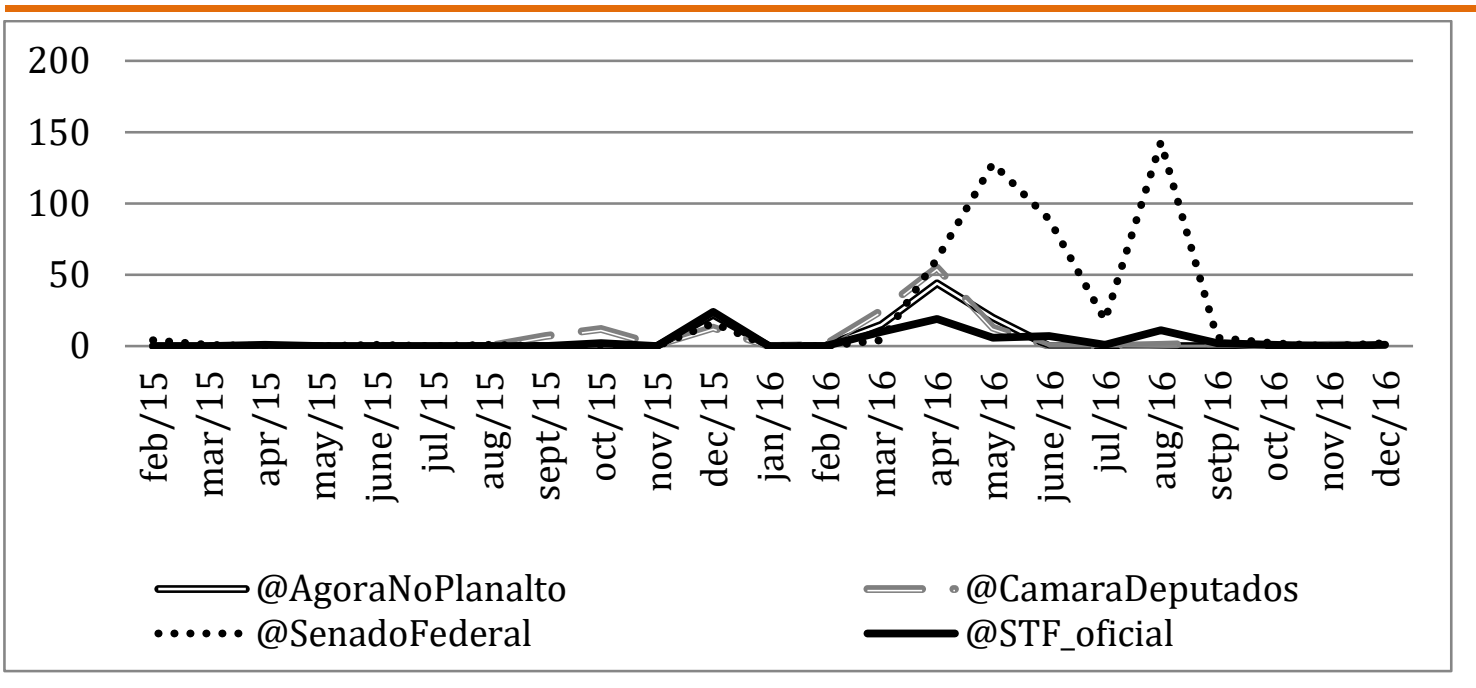

Source: Elaborated by the authors, with data from Twitter.

Graph 01 makes it clear that the first moment with a simultaneous tweet/keyword peak was December 2015 - the moment when the impeachment proposal presented to the Chamber of Deputies was accepted by president of the Chamber Eduardo Cunha. A total of 71 tweets were posted in that month, with the Federal Supreme Court profile, with 24 posts, being the most active.

The second moment with the highest number of tweets occurred in April 2016, when Dilma Rousseff's removal was voted on in a Chamber of Deputies plenary session. The total number for the month, adding together posts from all four profiles, was 179. The Federal Senate was the most active profile at the time, reaching 61 tweets. In April, the Presidential Palace profile reached its maximum number of tweets per month during the period studied, with 44 messages.

In May 2016, the Federal Senate profile published 128 tweets. May was the month with the second-highest number of posts coming from the Federal Senate, second only to August 2016, when it published the keywords 148 times (August, 
incidentally, was the month when Federal Senate permanently removed Dilma from office, which shows clear synchronization between communication and politics).

The Presidential Palace profile posted 101 tweets in the period we studied. They were concentrated within four months: 22 posts in December 2015; 15 in March 2016; 44 in April 2016; and 20 in May 2016 (when the Chamber of Deputies suspended the mandate of President Rousseff and Michel Temer (MDB) took office). After May 2016, words referring to impeachment were no longer used by the Presidential Palace profile. Even though the impeachment process continued in the Federal Senate, the Presidential Palace ceased to address the issue.

Now that we have presented the temporal distribution of the posts, it is time to look at the qualitative dimension. We first considered the frequency of direct interaction between institutional profiles and other users, whether through retweet, response or direct mention. This is an essential source of data to verify our hypothesis, as it helps us investigate the extent to which political instrumentalization manifests itself through mentions of political actors - accounts from other users can be used to reinforce an opinion, for example. Graph 02 shows the quantity of interactions.

We wish to point out that the Chamber and the STF profiles did not interact with any other Twitter profiles. In other words, they focused on content they produced themselves. The profiles of the Presidential Palace and the Federal Senate published 23 and 117 interactive tweets, respectively. In other words, interaction occurred in $22.7 \%$ of the Presidential Palace tweets and $24.5 \%$ of the Senate tweets. It should also be noted that among the 23 interactions engaged in by the Presidential Palace profile, 14 were directed directly at the former President Rousseff. On the other nine occasions, the Presidential Palace's interactive posts were directed at various parties, such as ministers, the Federal Attorney General and news media (@Veja, @RevistaISTOE and @RevistaEpoca). “Prefeitos repudiam impeachment e dizem que processo contra @Dilmabr desestabiliza País http://goo.gl/zgjLJe" ["Mayors reject impeachment and say investigation against @Dilmabr destabilizes the Country"] $]^{4}$.

${ }^{4}$ Presidential Palace, Twitter Post, 12/14/2015, <https://bit.ly/2GXGCS2>. 
Graph 02. Tweets with interactions by profile

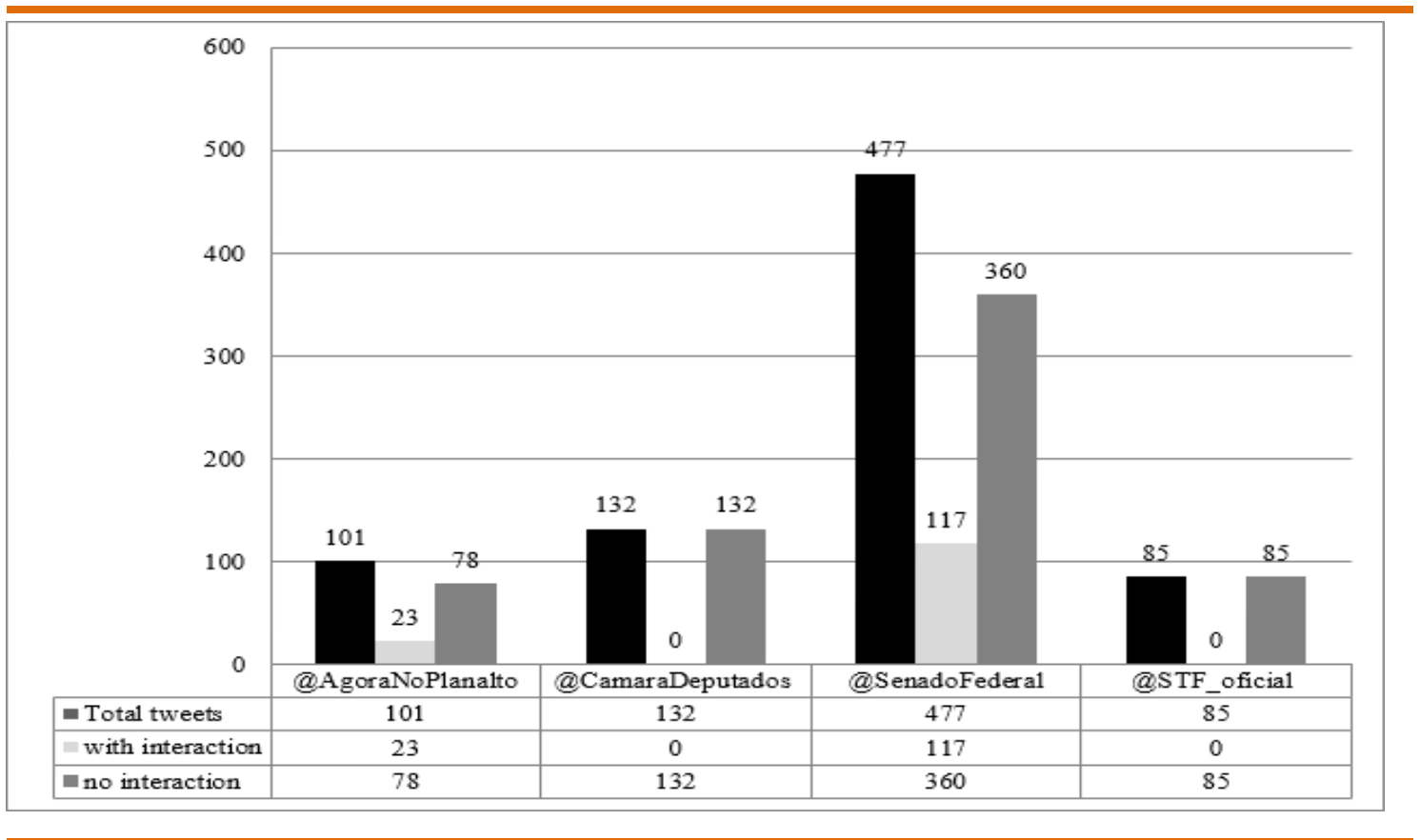

Source: Elaborated by the authors, with data from Twitter.

At times, the Presidential Palace profile also highlighted the support of other political personalities for Rousseff, tagging their profiles: “@jaqueswagner: (...) "Tenho convicção de que ele acha, como nós, que não há lastro para impeachment" ["I am convinced that he thinks, like us, that there is no basis for impeachment." $]^{5}$. And "Usar impeachment para resolver problema político é afronta à democracia, avalia ministro @edinhosilva" [Using impeachment to solve political problems is an affront to democracy, in the opinion of minister @edinhosilva] ${ }^{6}$.

The Senate profile interacted in 117 tweets, with 35 of its messages referring to Senator Antonio Anastasia from the PSDB party (@Anastasia), the deputy responsible for reporting to the Special Impeachment Commission established in Congress. The other mentions made by the Senate profile dealt, in general, with the positions of several senators regarding the trial.

5Presidential Palace, Twitter Post, 12/03/2015, < https://twitter.com/planalto/status/672427021591560192>. 6Presidential Palace, Twitter Post, 12/03/2015, <https://twitter.com/planalto/status/672542679528562690>. 
“A Comissão do Impeachment vai votar o relatório do senador @Anastasia, que é favorável à admissibilidade do processo" [The Impeachment Commission will vote on Senator @Anastasia's report, which favors the admissibility of the trial]?7.

Federal Senate posts that interact with other profiles highlighted Congressional support both for and against Rousseff's removal and reported regularly on the process. Thus, it can be noted that the Senate presents a less instrumentalized partisan communication posture when compared to the Presidential Palace.

“@lasiermartins: há elementos jurídicos e políticos para o impeachment" [“@Lasiermartins: there are legal and political grounds for impeachment”] ${ }^{8}$. And “@LindbergFarias: 'Impeachment é golpe e nós vamos resistir ao governo Temer” [“The impeachment is a coup and we are going to fight back against the Temer government"] 9 .

We then verified the type of content emphasized by these publications. For this, the 795 tweets were classified according to the seven categories proposed in the methodology section: 01. steps in the impeachment process; 02. media agenda; 03. dissemination of news; 04. reporting on political achievements; 05 . criticism and negative campaigning; 06. promotion of ideas and expression of positions; 07. other.

Of the 795 tweets, the most frequent content referred to 'dissemination of news', with 408 posts, representing $51.32 \%$ of the total tweets. The second most published type of content was 'steps in the impeachment process', with 152 tweets (19.12\% of the total). 'Promotion of ideas and expression of positions' comes close behind, reaching 150 tweets (18.87\% of total posts). Table 04 presents the distribution of the total content of the profiles we examined.

It should be noted that 629 tweets (79.12\% of the corpus) were classified into one of the categories that identify an instance of public communication as tending toward what the literature defines as normative ('dissemination of news', 'steps in the impeachment process' and 'media agenda'). One hundred fifty-seven tweets $(18.7 \%)$ were classified into the categories that identify the use of Twitter as

${ }^{7}$ Federal Senate, TwitterPost, 05/06/2016, <https://bit.ly/2IRf4zC>.

${ }^{8} \mathrm{Federal}$ Senate, TwitterPost, 08/09/2016, <https://twitter.com/SenadoFederal/status/763147405902671873>.

${ }^{9}$ Federal Senate, TwitterPost, 08/09/2016, <https://twitter.com/SenadoFederal/status/763150200756142081>. 
a partisan communication tool ('promotion of ideas and expression of positions', 'criticism and negative campaigning' and 'reporting of political achievements').

Table 04. Topics of posts published by the profiles

\begin{tabular}{lcc}
\hline Content & Frequency & Percentage \\
\hline Dissemination of news & 408 & $51.32 \%$ \\
Steps in the impeachment process & 152 & $19.12 \%$ \\
Promotion of ideas and expression of positions & 150 & $18.87 \%$ \\
Media agenda & 69 & $8.68 \%$ \\
Others & 09 & $1.13 \%$ \\
Criticism and negative campaigning & 05 & $0.63 \%$ \\
Reporting of political achievements & 02 & $0.25 \%$ \\
Total & 795 & $100 \%$ \\
\hline
\end{tabular}

Source: Elaborated by the authors, with data from Twitter.

Table 05 shows the types of content each of the four profiles published over the 24-month period. In addition to the frequencies, percentages and standardized residuals, the same table shows the respective chi-squared and Cramér's V values. The chi-squared value indicates that there is a statistically significant association between the variables of 'Twitter profile' and 'content' (their distributions do not occur independently), while the Cramér's $\mathrm{V}$ value shows that this association is moderate, occurring in $38 \%$ of cases.

It is clear from the table below that the Presidential Palace profile mainly published tweets in the 'promotion of ideas and expression of positions' category: 80 of the total 101 analyzed posts made some kind of value judgment about the ongoing political process. In addition, the Presidential Palace's Twitter account alone posted $53.30 \%$ of all corpus tweets in this category. This fact is evidenced by the strength of the standardized residual ${ }^{10}$ (s.r. 14). We note that, in addition to the high percentage of messages related to political positioning, the Presidential Palace profile published 43 tweets specifically containing the word 'golpe' ('coup'), indicating a clear position against impeachment.

\footnotetext{
${ }^{10}$ The standardized residual permits a direct comparison between values; it identifies the difference between observed and expected values in a distribution. In the confidence interval we applied of $95 \%$, any value beyond $+/-1.96$ is statistically significant (FIELD, 2005).
} 
Table 05. Types of content published by profile and residuals

\begin{tabular}{|c|c|c|c|c|c|c|}
\hline & & $\begin{array}{l}\text { Pres. } \\
\text { Palace }\end{array}$ & $\begin{array}{c}\text { Chamber of } \\
\text { Deputies }\end{array}$ & $\begin{array}{l}\text { Federal } \\
\text { Senate }\end{array}$ & STF & Total \\
\hline \multirow{3}{*}{$\begin{array}{l}\text { Steps in the } \\
\text { impeachment } \\
\text { process }\end{array}$} & Count (n) & 0 & 23 & 128 & 01 & 152 \\
\hline & $\%$ & $0.0 \%$ & $15.1 \%$ & $84.2 \%$ & $0.7 \%$ & $100.0 \%$ \\
\hline & Standardized residual & -4.4 & -.4 & 3.9 & -3.8 & \\
\hline \multirow[t]{3}{*}{ Media agenda } & Count $(\mathrm{n})$ & 02 & 21 & 42 & 04 & 69 \\
\hline & $\%$ & $2.9 \%$ & $30.4 \%$ & $60.9 \%$ & $5.8 \%$ & $100.0 \%$ \\
\hline & Standardized residual & -2.3 & 2.8 & , & -1.2 & \\
\hline \multirow{3}{*}{$\begin{array}{l}\text { Dissemination of } \\
\text { news }\end{array}$} & Count (n) & 16 & 78 & 240 & 74 & 408 \\
\hline & $\%$ & $3.9 \%$ & $19.1 \%$ & $58.8 \%$ & $18.1 \%$ & $100.0 \%$ \\
\hline & Standardized residual & -5.0 & 1.2 & -.3 & 4.6 & \\
\hline \multirow{3}{*}{$\begin{array}{l}\text { Reporting on } \\
\text { political } \\
\text { achievements }\end{array}$} & Count $(\mathrm{n})$ & 01 & 01 & 0 & 0 & 02 \\
\hline & $\%$ & $50.0 \%$ & $50.0 \%$ & $0.0 \%$ & $0.0 \%$ & $100.0 \%$ \\
\hline & Standardized residual & 1.5 & 1.2 & -1.1 & -.5 & \\
\hline \multirow{3}{*}{$\begin{array}{l}\text { Criticism and } \\
\text { negative } \\
\text { campaigning }\end{array}$} & Count (n) & 02 & 0 & 03 & 0 & 05 \\
\hline & $\%$ & $40.0 \%$ & $0.0 \%$ & $60.0 \%$ & $0.0 \%$ & $100.0 \%$ \\
\hline & Standardized residual & 1.7 & -.9 & 0.0 & -.7 & \\
\hline Average & Count (n) & 80 & 09 & 55 & 06 & 150 \\
\hline \multirow{2}{*}{$\begin{array}{l}\text { Promotion of ideas } \\
\text { and expression of } \\
\text { positions }\end{array}$} & $\%$ & $53.3 \%$ & $6.0 \%$ & $36.7 \%$ & $4.0 \%$ & $100.0 \%$ \\
\hline & Standardized residual & 14.0 & -3.2 & -3.7 & -2.5 & \\
\hline \multirow[t]{3}{*}{ Others } & Count (n) & 0 & 0 & 09 & 0 & 09 \\
\hline & $\%$ & $0.0 \%$ & $0.0 \%$ & $100.0 \%$ & $0.0 \%$ & $100.0 \%$ \\
\hline & Standardized residual & -1.1 & -1.2 & 1.5 & -1.0 & \\
\hline \multirow[t]{2}{*}{ Total } & Count (n) & 101 & 132 & 477 & 85 & 795 \\
\hline & $\%$ & $12.7 \%$ & $16.6 \%$ & $60.0 \%$ & $10.7 \%$ & $100.0 \%$ \\
\hline
\end{tabular}

Source: Elaborated by the authors, with data from Twitter.

Note: Chi-squared $=351.66(p=0.000)$; Cramér's V = 0.384 .

In the Chamber of Deputies' profile, the type of content most posted was 'dissemination of news', with 78 tweets (about 59\% of this profile's total). However, the most powerful theme was 'media agenda', with a standardized residual of 2.8; posts containing 'positioning' were the weakest (s.r. -3.2). It is therefore possible to infer that the Chamber of Deputies attempted to avoid passing value judgments about the process.

As stated earlier, the Federal Senate profile published 477 tweets mentioning at least one of the four terms in the reporting period, representing about $60 \%$ of the total corpus. In the case of the Senate, the most prevalent content was that related to 'dissemination of news', with 240 tweets (about 50\% of the total 
posted by this profile). Then came 'steps in the impeachment process' with 128 tweets and 'promotion of ideas and expression of positions' with only 55 tweets. It should be noted that the theme with the greatest strength was 'steps in the impeachment process', with a standardized residual of 3.90. Only 18 posts from the Federal Senate mentioned the word 'golpe'; these tweets reported, in their majority, the positions of government senators opposed to impeachment. Therefore, even when mentioning the term 'golpe', the Federal Senate profile was careful to ascribe this word to other political actors, avoiding having to assume any direct position. This is what happens in the following example, in which the Senate mentions Jorge Viana (PT): “@jorgeviana diz que Dilma está sofrendo um golpe parlamentar” [“@Jorgeviana says Dilma is the victim of a parliamentary coup $]^{11}$.

It is noteworthy, moreover, that all tweets classified into the 'other' category - tweets that do not fit any of the outlined categories- were published by the Federal Senate. "Quem é quem no processo de impeachment?" ["Who's who in the impeachment process?"] ${ }^{12}$.

The Federal Supreme Court profile published 85 tweets featuring one of the four keywords, the most recurring content being 'dissemination of news', with 74 tweets (representing approximately $87 \%$ of total posts from this profile). It is also noteworthy that the relevance of this content in numerous STF posts is also perceived by the strength of the standardized residual of 4.60. This profile's interest in avoiding expressing any position is evident, as the profile published only six tweets related to the 'promotion of ideas and expression of positions' category - the lowest among the four institutions (s.r. -2.50). It is noteworthy that no STF tweet used the word 'golpe'.

"Para min Toffoli, a autorização da Câmara para o processo de impeachment não dá margens para recusa do Senado" ["For Justice Toffoli, the Chamber's

\footnotetext{
${ }^{11}$ Federal Senate, Twitter Post, 08/09/2016, <https://goo.gl/gKqKBE>.

${ }^{12}$ Federal Senate, Twitter Post, 08/25/2016, <https://twitter.com/SenadoFederal/status/768872835217522688>.
} 
authorization of the impeachment process does not leave any space for the Senate to refuse"] ${ }^{13}$.

By further differentiating the categories related to normative public communication ('dissemination of news', 'steps in the impeachment process' and 'media agenda') and the categories that identify instrumentalization of political communication ('promotion of ideas and expression of positions', 'criticism and negative campaigning' and 'reporting of political achievements'), the sum of the first categories by profile are: 16 tweets from the Presidential Palace; 122 from the Chamber of Deputies; 410 from the Federal Senate; and 79 from the STF. The categories relating to partisan instrumentalization of communication were made up of 83 tweets from the Presidential Palace, ten from the Chamber of Deputies, 58 from the Senate and only six from the STF. The Presidential Palace, therefore, was the only profile that instrumentalized its communication channel in an effort to favor a specific set of political actors.

The association between the accounts analyzed and the topics posted about is more evident in Graph 03, which identifies - through correspondence analysis - the degree of association between the institutional profiles and the themes into which their tweets were classified.

Visual display of the information supports the finding that the Presidential Palace profile, isolated on the right side of the graph, is close to 'promotion of ideas and expression of positions', 'criticism and negative campaigning' and 'reporting of political achievements' topics. The other three profiles can be found on the left side of the chart, with only the STF next to the theme 'dissemination of news'. The Chamber of Deputies' profile, on the other hand, is situated between 'dissemination of news' and 'media agenda', while the Federal Senate account is closer to the 'steps in the impeachment process' and 'media agenda' categories. It should also be noted that 'promotion of ideas and expression of positions' predominates in the Presidential Palace profile, with a high positive standardized residual (s.r. 14), while the other three profiles present negative residuals for this category: Chamber of Deputies (s.r. -3.2), Federal Senate (s.r. -3.7), Federal Supreme Court (s.r. -2.5). We will now move to key research findings based on relevant literature.

\footnotetext{
${ }^{13}$ Federal Supreme Court, Twitter Post, 12/17/2015, <https://bit.ly/2tL7cFw $>$.
} 
Graph 03. Correspondence between posted themes and profiles

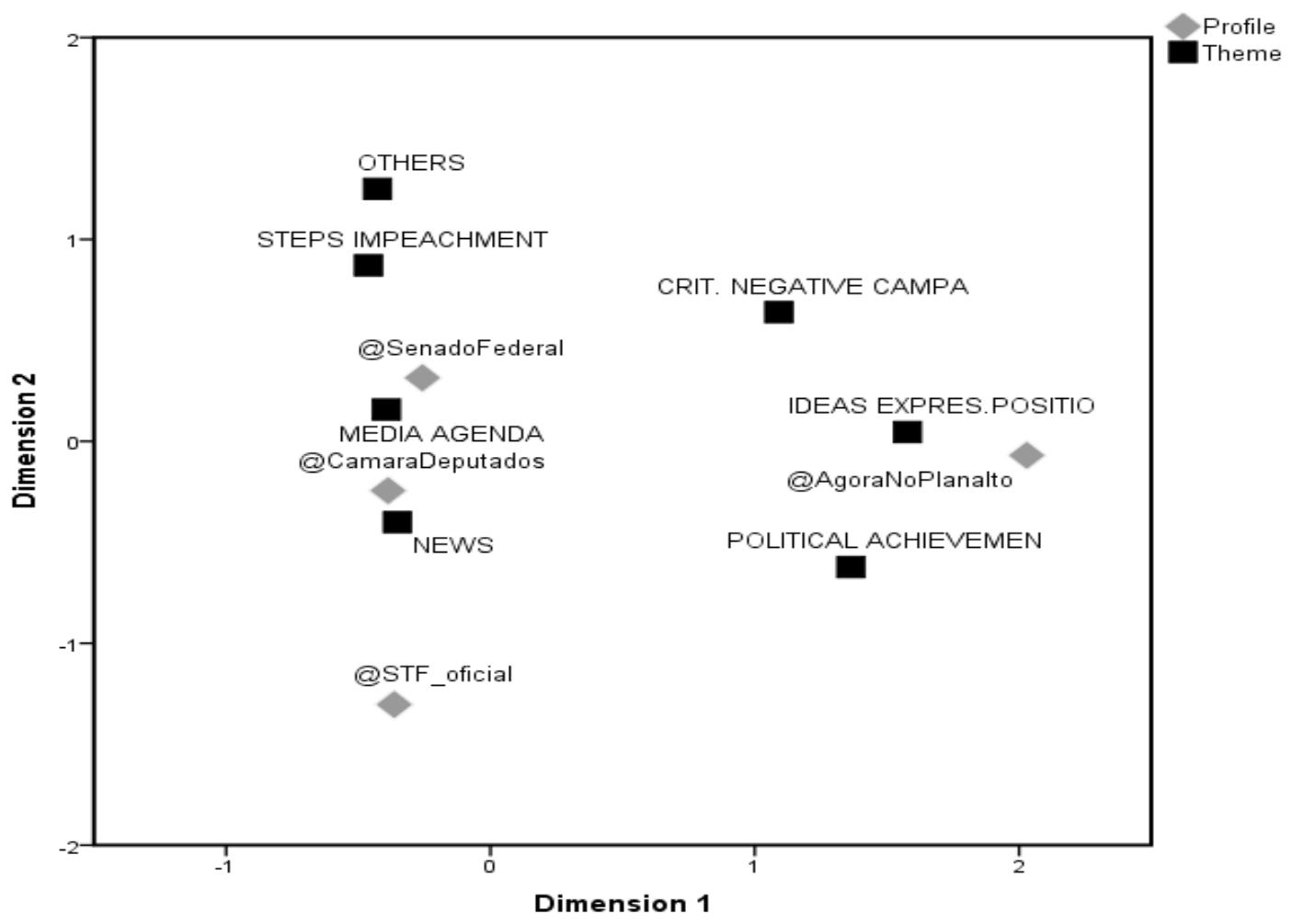

Source: Elaborated by the authors, with data from Twitter.

Note: Total inertia $=0.442$; inertia of dimension $1=0.362$; inertia of dimension $2=0.063$.

\section{Discussion of the results and conclusions}

This article proposed two objectives: to classify and understand the content relating to the impeachment process published on the Twitter profiles administered by the Chamber of Deputies, Federal Senate, Presidential Palace and Federal Supreme Court; and to verify whether and to what extent, there was any instrumentalization of official communication platforms for partisan purposes. Our working hypothesis was that the official Twitter profiles managed by State institutions emphasize the publication of posts promoting political position-taking. This indicates the instrumentalization of the available communication tools.

Given the results, it can be concluded that our hypothesis has been only partially confirmed, since instrumentalization of public communication for partisan interests occurred only on the Presidential Palace's profile. This profile favored positioning-taking tweets (i.e., anti-impeachment tweets) and when the profile did interact with other profiles, it tended to mention the profile of Dilma Rousseff. 
Although the other three profiles adopted a different Twitter utilization strategy (in terms of the frequency of publications, interactions with other users and the nature of posted content), we noted that the Chamber of Deputies and the Federal Supreme Court emphasized the dissemination of news. The Senate account tended to post on the steps in the impeachment process. That is to say that the predominant categories of content published by these three accounts are related to normative public communication.

The profile of the Presidential Palace, especially in the period before April 2016 (Rousseff was temporarily removed from office in May of that year), adopted a defensive position vis-à-vis the impeachment, with most of its tweets falling into the category 'promotion of ideas and expression of positions'. The Presidential Palace was the only of the four entities that presented more content related to 'positioning' than 'news'. This demonstrates how the Presidential Palace was more concerned with criticizing or coming out against the situation, especially by using the term 'golpe'. Moreover, the fact that the Presidential Palace profile stopped mentioning the impeachment as soon as Rousseff was suspended reinforces the impression that the profile had been politically instrumentalized. The Presidential Palace profile's behavior, therefore, reinforces the diagnosis of instrumentalization of public communication.

It is not surprising that the Presidential Palace profile adopted the stance identified here - especially because it is more directly linked to the construction of the image of the then president and her administration. The profiles of the two legislative houses, on the other hand, are more informative because of the number of members (and their various parties) who hold office in Congress (even though these institutional profiles highlight the positions of representatives who have conflicting worldviews).

This finding refutes the assertion that Deputy Eduardo Cunha (MDB) had completely taken over and instrumentalized the communication tools of the Chamber of Deputies. Even though Cunha is accused of emphasizing coverage of subjects of his particular interest using the TV Câmara service (GALVÃO, 2016), the same cannot be said for the publications made on the institution's official Twitter 
profile. We therefore signal the need to investigate the possibility that political administrators pay more attention to certain communication platforms than others.

None of the tweets published by the STF was concerned with promoting interactions. The Chamber of Deputies followed the same pattern and did not mention or replicate content from other accounts. The Senate interacted with other profiles with some regularity, but the focus was on giving visibility to the words of several senators - particular attention was given to the profile of Senator Anastasia, the lower house impeachment rapporteur. The Presidential Palace also dedicated part of its posts to interaction but in most cases associated such interaction with a political position - giving visibility to Dilma Rousseff's personal profile.

In line with the literature, it can be argued that despite the alleged democratizing and responsive character of social networking sites (BERTOT, JAEGER and GRIMES, 2010; MARGETTS, 2011), Twitter was hardly used to increase interaction and collaboration between public institutions and other users of the network. This low level of interaction also goes against Coombs' (2007) view that entities are more likely to interact in online environments in times of crisis because they must protect their reputations.

In this regard, Perry, Taylor and Doerfel's (2003) argument makes more sense. They argue that different organizations have made efforts to use digital communication tools in crisis management situations and in struggles to establish a certain image. By using digital social media, one can gather the impressions of the public of events involving organizations (although this interactive dimension has taken a back seat in our case), as well as improving communication with news media in order to obtain more favorable coverage.

Another important aspect is the fact that the frequency of publication of tweets by the profiles we looked at reflected the political-institutional development of the impeachment processes. In other words, the institutions examined here practically ignored the street demonstrations for and against Dilma Rousseff's impeachment ${ }^{14}$ - or at least did not use the keywords contemplated by this investigation in those posts aired during the protests, as can be seen in the low occurrence

\footnotetext{
${ }^{14}$ See: <https://www.nytimes.com/2015/03/21/world/americas/brazils-slumping-economy-and-
} bribery-scandal-eat-away-at-dilma-rousseffs-popularity.html>. Accessed on August, 22, 2018. 
of the terms in March 2015 (Graph 01). Officials preferred to pay attention to the process only after it was formally constituted within the Legislative Branch.

There are other peculiarities regarding political uses of digital communication that must be noted at this point. Interestingly, in December 2015 (the month in which the Chamber of Deputies agreed to evaluate the impeachment request), the STF profile was the one that published the most tweets containing the keywords considered here. This can be explained by its addressing questions especially by the initiative of parliamentarians - about the formal processes of impeachment. During April and May 2016, the profiles with the highest number of posts were the Chamber of Deputies (68 tweets) and the Federal Senate (189 tweets), as there were decisive votes on Dilma's impeachment in both houses.

Additionally, official communication on Twitter is relevant not only because it presents specific worldviews of events, but because it occupies a social space that enables it to influence other actors participating in debates. Media organizations serve as an example, as they, in addition to' reporting on the impeachment, also expressed themselves through editorial statements (MARQUES, MONTALVERNE and MITOZO, 2018). For this reason, the interaction between State and media entities in times of acute democratic crisis should be deepened, as this is when their very solidity and credibility are called into question (ALBUQUERQUE, 2017).

We cannot ignore the fact that the communication structures available to each State entity may vary, directly affecting how they respond to crises. In this sense, the performance of State entities depends not only on external pressures faced by them and their leaders but is also - as Greening and Gray (1994) argue associated with the amount of resources (personnel and financial) allocated to them in a given situation.

Before concluding the article, we would like to point out that this work's novelty lies in its study of State institutions' use of social media, thus contributing to the literature on public communication via digital social media. The analytical framework designed and presented here may be useful for other works that seek to examine moments of severe institutional crisis. The data we obtained are consistent with the separation of public communication into two dimensions, as practiced by previous authors (MIOLA and MARQUES, 2017; WEBER, 2007). 
We recognize that the choice of four keywords may have limited our capacity to diagnose institutional communication on Twitter. By specifically emphasizing the terms linked to the impeachment process, other tweets related to the Brazilian political crisis may have been overlooked. However, we believe that the categories created to address the content analysis were sufficient to capture the discursive postures of the four entities we looked at in the most relevant moments of the crisis.

In our view, future research should focus on comparing the different ways that the Executive, Legislative and Judiciary use their communication channels at different administrative levels. This is because other studies in the area have already drawn attention to the need to consider sociability as a dimension that influences the use of digital media for political purposes (HUGHES et al., 2012; HERMAN, 2017). Moreover, it is necessary to study the use of these communication channels at times other than during political crises; analysis of these at other times may lead to different findings from those presented in this study.

Translated by Fraser Robinson Submitted on October 20, 2018

Accepted on June 08, 2019

\section{References}

AGGIO, Camilo de Oliveira (2016), Campanhas online e twitter: a interação entre campanhas e eleitores nas eleições presidenciais brasileiras de 2010. Revista Famecos. Vol. 23, № 01, pp. 01-27.

AHARONY, Noa (2012), Twitter use by three political leaders: an exploratory analysis. Online Information Review. Vol. 36, № 04, pp. 587-603.

ALBUQUERQUE, Afonso (2017), Protecting democracy or conspiring against it? Media and politics in Latin America: a glimpse from Brazil. Journalism. Vol. 20, № 07, pp. 906-923.

ALONSO, Angela Maria (2017), A política das ruas: protestos em São Paulo de Dilma a Temer. Novos Estudos. pp. 49-58.

BARDIN, Laurence (1977), Análise de conteúdo. Lisboa: Edições 70. 229 pp..

BARROS, Najara Lima de and MIOLA, Edna (2015), Comunicação pública de estado nas redes sociais: uma análise do perfil do governo de Sergipe no Twitter. Paper. Anais do VI Encontro da Compolítica. Pontifícia Universidade Católica do Rio de Janeiro. 
BAXTER, Graeme; MARCELLA, Rita, and O'SHEA, Mary (2016), Members of the Scottish Parliament on Twitter: good constituency men (and women)?. Aslib Journal of Information Management. Vol. 68, № 04, pp. 428-447.

BERTOT, John Carlo; JAEGER, Paul T., and GRIMES, Justin M. (2010), Promoting transparency and accountability through ICTs, social media and collaborative egovernment. Transforming Government: People, Process and Policy. Vol. 06, № 01, pp. 78-91.

BOIN, Arjen; HART, Paul't, and McCONNELL, Allan (2009), Crisis exploitation: political and policy impacts of framing contests. Journal of European Public Policy. Vol. 16, № 01, pp. 81-106.

BOR, Stephanie E. (2013), Using social network sites to improve communication between political campaigns and citizens in the 2012 Election. American Behavioral Scientist. Vol. 58, № 09, pp. 1195-1213.

BRASIL (2015), Pesquisa Brasília de Mídia. Secretaria de Comunicação Social. Presidência da República. Available at <http://www.secom.gov.br/atuacao/pesquisa/lista-de-pesquisas-quantitativase-qualitativas-de-contratos-atuais/pesquisa-brasileira-de-midia-pbm2015.pdf/view>. Accessed on March, 03, 2018.

BRASIL (2014), Manual de orientação para atuação em mídias sociais. Secretaria de Comunicação Social. Presidência da República. Available at $<h t t p: / / w w w . s e c o m . g o v . b r / p d f$-da-area-de-orientacoes-gerais/internet-eredes-sociais/secommanualredessociaisout2012_pdf.pdfs. Accessed on August, 22, 2018.

BUCCI, Eugênio (2015), O Estado de Narciso: a comunicação pública a serviço da vaidade particular. São Paulo: Companhia das Letras. 248 pp..

CAMPILLO-ALHAMA, Concepción and MARTÍNEZ-SALA, Alba-Maria (2017), Integrated communication 2.0 in municipal administration. El Profesional de la Información. Vol. 26, № 03, pp. 1699-2407.

CANEL, María and SANDERS, Karen (2016), Government communication. In: The international encyclopedia of political communication. Vol. 02. Edited by MAZZOLENI, Gianpietro. Chichester: John Wiley \& Sons. pp. 01-08.

CASERO-RIPOLLÉS Andreu; SINTES-OLIVELLA, Marçal, and FRANCH, Pere (2017), The populist political communication style in action: Podemos's issues and functions on Twitter during the 2016 Spanish General Election. American Behavioral Scientist. Vol. 61, № 09, pp. 986-1001. 
CONRAD, Charles and TERRY, Andrea (2015) Strategic communication. In: The international encyclopedia of political communication. Vol. 03. Edited by MAZZOLENI, Gianpietro. Chichester: John Wiley \& Sons. pp. 01-11.

COOMBS, Timothy (2007), Protecting organization reputations during a crisis: the development and application of situational crisis communication theory. Corporate Reputation Review. Vol. 10, № 03, pp. 163-176.

EBERWEIN, Tobias; PORLEZZA, Colin, and SPLENDOR, Sergio (2016), Media as political Actor. In: The international encyclopedia of political communication. Vol. 02. Edited by MAZZOLENI, Gianpietro. Chichester: John Wiley \& Sons. pp. 01-09.

ENLI, Gunn (2017), Twitter as arena for the authentic outsider: exploring the social media campaigns of Trump and Clinton in the 2016 US presidential election. European Journal of Communication. Vol. 32, № 01, pp. 50-61.

ENLI, Gunn Sara and SKOGERBØ, Eli (2013), Personalized campaigns in partycentred politics: Twitter and Facebook as arenas for political communication. Information, Communication \& Society. Vol. 16, № 05, pp. 01-18.

EVANS, Heather K.; CORDOVA, Victoria, and SIPOLE, Savannah (2014), Twitter style: an analysis of how house candidates used Twitter in their 2012 campaigns. PS: Political Science \& Politics. Vol. 47, № 02, pp. 454-462.

FIELD, Andy (2005), Discovering Statistics with SPSS. London: Sage. 856 pp..

GALVÃO, Rosane Queiroz (2016), A construção semiótica e discursiva do impeachment no parlamento brasileiro. Trabalhos Completos ALED BRASIL. Vol. 02, № 04, pp. 01-15.

GOLBECK, Jennifer; GRIMES, Justin M., and ROGERS, Anthony (2010), Twitter use by the US Congress. Journal of the American Society for Information Science and Technology. Vol. 61, № 08, pp. 1612-1621.

GOMES, Wilson (2005), A democracia digital e o problema da participação civil na decisão política. Fronteiras-Estudos Midiáticos. Vol. 07, № 03, pp. 214-222.

GOMES, Wilson; FERNANDES, Breno; REIS, Lucas, and SILVA, Tarcizio (2009), 'Politics 2.0': a campanha online de Barack Obama em 2008. Revista de Sociologia e Política. Vol. 17, № 34, pp. 29-43.

GRABER, Doris A. (2002), The power of communication: managing information in public organizations. Washington: SAGE. 294 pp..

GREENING, Daniel W. and GRAY, Barbara (1994), Testing a model of organizational response to social and political issues. Academy of Management Journal. Vol. 37, № 03, pp. 467-498. 
HAIR JR., Joseph; BLACK, William; BABIN, Barry; ANDERSON, Rolph, and TATHAM, Ronald (2009), Análise multivariada de dados. Porto Alegre: Bookman. 688 pp..

HART, Paul't (1993), Symbols, rituals and power: the lost dimensions of crisis management. Journal of Contingencies and Crisis Management. Vol. 01, № 01, pp. 36-50.

HAYES Andrew F. and KRIPPENDORFF, Klaus (2007), Answering the call for a standard reliability measure for coding data. Communication Methods and Measures. Vol. 01, № 01, pp. 77-89.

HEMSLEY, Jeff; STROMER-GALLEY, Jennifer; SEMAAN, Bryan, and TANUPABRUNGSUN, Sikana (2018), Tweeting to the target: candidates' use of strategic messages and @mentions on Twitter. Journal of Information Technology \& Politics. Vol. 15, № 01, pp. 03-18.

HERMAN, Fellipe (2017), Campanhas online e sociabilidade política. Master's dissertation. Programa de Pós-Graduação em Ciência Política. Universidade Federal do Paraná.

HONEYCUTT, Courtenay and HERRING, Susan C. (2009), Beyond microblogging: conversation and collaboration via Twitter. Paper. Anais do 42nd Hawaii International Conference on System Sciences.

HUGHES, David John; ROWE, Moss; BATEY, Mark, and LEE Andrew (2012), A tale of two sites: Twitter vs. Facebook and the personality predictors of social media usage. Computers in Human Behavior. Vol. 28, № 02, pp. 561-569.

JACKSON, Nigel and LILLEKER, Darren (2011), Microblogging, constituency service and impression management: UK MPs and the use of Twitter. The Journal of Legislative Studies. Vol. 17, № 01, pp. 86-105.

JAMBEIRO, Othon (2002), A TV no Brasil do século XX. Salvador: Edufba. 206 pp..

JUNGHERR, Andreas (2016), Four functions of digital tools in election campaigns: the German case. The International Journal of Press/Politics. Vol. 21, № 03, pp. 358-377.

KHAN, Gohar; YOON, Ho Young, and PARK, Han Woo (2014), Social media communication strategies of government agencies: Twitter use in Korea and the USA. Asian Journal of Communication. Vol. 24, № 01, pp. 60-78.

KRIPPENDORFF, Klaus (2004), Reliability in content analysis some common misconceptions and recommendations. Human Communication Research. Vol. 30, № 03, pp. 411-433. 
LARSSON, Anders 0. and KALSNES, Bente (2014), 'Of course we are on Facebook': use and non-use of social media among Swedish and Norwegian politicians. European Journal of Communication. Vol. 29, № 06, pp. 653-667.

LASHLEY, Marily (1992), Even in public television, ownership changes matter. Communication Research. Vol. 19, № 06, pp. 770-786.

LASSEN, David S. and BROWN, Adam R. (2011), Twitter: the electoral connection?. Social Science Computer Review. Vol. 29, № 04, pp. 419-436.

LEE, Nicole and VANDYKE, Matthew (2015), Set it and forget it: the one-way use of social media by government agencies communicating science. Science Communication. Vol. 37, № 04, pp. 533-541.

MAIA, Rousiley C. M.; BOTELHO, Juliana Santos, and MUNDIM, Pedro Santos (2011), 0 debate em torno das cotas nas universidades públicas brasileiras de $2001 \mathrm{a}$ 2009: uma análise preliminar. Revista Compolítica. Vol. 01, № 02, pp. 08-34.

MARGETTS, Helen (2011), The Internet and transparency. The Political Quarterly. Vol. 82, № 04, pp. 518-521.

MARQUES, Francisco Paulo Jamil Almeida; AQUINO, Jakson Alves de, and MIOLA, Edna (2014), Parlamentares, representação política e redes sociais digitais: perfis de uso do Twitter na Câmara dos Deputados. Opinião Pública. Vol. 20, № 02, pp. 178-203.

MARQUES, Francisco Paulo Jamil and MONT'ALVERNE, Camila (2016), How important is Twitter to local elections in Brazil? A case study of Fortaleza City Council. Brazilian Political Science Review. Vol. 10, № 03, pp. 01-35.

MARQUES, Francisco Paulo Jamil; MONT’ALVERNE, Camila, and MITOZO, Isabele Batista (2018), A empresa jornalística como ator político: um estudo quantiqualitativo sobre o impeachment de Dilma Rousseff nos editoriais de Folha e Estadão. Observatorio (OBS*). Vol. 12, № 03, pp. 224-245.

MERGEL, Ines (2013), A framework for interpreting social media interactions in the public sector. Government Information Quarterly. Vol. 30, № 04, pp. 327-334.

MIOLA, Edna (2009), Radiodifusão pública e participação deliberativa: um estudo das características e dos modos de atuação do Conselho Deliberativo da FCPRTVE. Master's dissertation. Faculdade de Comunicação. Universidade Federal da Bahia.

MIOLA, Edna and MARQUES, Francisco Paulo Jamil (2017), Por uma definição de comunicação pública: tipologias e experiências brasileiras. Paper. Anais do VII Congresso da Associação Brasileira de Pesquisadores em Comunicação e Política. 
NIELSEN, Rasmus Kleis and VACCARI, Cristian (2013), Do people 'like' politicians on Facebook? Not really. Large-scale direct candidate-to-voter online communication as an outlier phenomenon. International Journal of Communication. Vol. 07, pp. 2333-2356.

OTT, Brian L. (2017), The age of Twitter: Donald J. Trump and the politics of debasement. Critical Studies in Media Communication. Vol. 34, № 01, pp. 59-68.

PARMELEE, John H. and BICHARD, Shannon L. (2011), Politics and the Twitter revolution: how tweets influence the relationship between political leaders and the public. New York: Lexington Books. 256 pp..

PÉREZ-LIÑÁN, Aníbal (2007), Presidential impeachment and the new political instability in Latin America. Cambridge: Cambridge University Press. 264 pp..

PERRY, Danielle C.; TAYLOR, Maureen, and DOERFEL, Marya L. (2003), Internetbased communication in crisis management. Management Communication Quarterly. Vol. 17, № 02, pp. 206-232.

RAMOS-SERRANO, Marina; GÓMEZ, Jorge David Fernández, and PINEDA, Antonio (2016), 'Follow the closing of the campaign on streaming': the use of Twitter by Spanish political parties during the 2014 European elections. New Media \& Society. Vol. 20, № 01, pp. 122-140.

ROSSINI, Patrícia Gonçalves da Conceição and LEAL, Paulo Roberto Figueira (2012), Os perfis de presidentes latino-americanos no Twitter: desafios da representação política no contexto da desintermediação comunicacional. Cadernos de Estudos Sociais e Políticos. Vol. 01, № 02, pp. 96-119.

RUEDIGER, Marco (2017), Robôs, redes sociais e política no Brasil: estudo sobre interferências ilegítimas no debate público na web, riscos à democracia e processo eleitoral de 2018. Available at <http://bibliotecadigital.tse.jus.br/xmlui/handle/bdtse/4433?show=full>. Accessed on August, 22, 2018.

SALLUM JR., Brasilio and CASARÕES, Guilherme Stole Paixão e (2011), 0 impeachment do presidente Collor: a literatura e o processo. Lua Nova. Vol. 82, pp. 163-200.

STURGES, David (1994), Communicating through crisis: a strategy for organizational survival. Management Communication Quarterly. Vol. 07, № 03, pp. 297-316.

TANDAZO, Carlos V. Granda; GALARZA, Fanny Y. Paladines, and BENAVIDES, Andrea V. Velásquez (2016), Digital strategic communication in Ecuador's public organisations: current state and future projection. Revista Latina de Comunicación Social. Vol. 71, pp. 211-231. 
UTZ, Sonja (2009), The (potential) benefits of campaigning via social network sites. Journal of Computer-Mediated Communication. Vol. 14, № 02, pp. 221-243.

VERGEER, Maurice; HERMANS, Liesbeth, and SAMS, Steven (2013), Online social networks and micro-blogging in political campaigning: the exploration of a new campaign tool and a new campaign style. Party Politics. Vol. 19, № 03, pp. 477501.

WEBER, Maria Helena (2007), Na comunicação pública, a captura do voto. LOGOS. Vol. 14, № 27, pp. 21-42.

WILLIAMS, Christine B. and GULATI, Girish Jeff (2013), Social networks in political campaigns: Facebook and the congressional elections of 2006 and 2008. New Media \& Society. Vol. 15, № 01, pp. 52-71.

ZÉMOR, Pierre (2012), As formas da comunicação pública. In: Comunicação pública: estado, mercado, sociedade e interesse público. Edited by DUARTE, Jorge. São Paulo: Atlas. pp. 214-245. 